\title{
Disposable gloves as an educational tool in teaching hand anatomy
}

Sir,

Disposable gloves are indispensable during operative procedures to maintain antisepsis. Since William S. Halstead's pioneering use of surgical gloves as a protective tool for a surgeon in 1896, numerous innovative uses of gloves have been documented, often in hand trauma. ${ }^{[1-3]}$ Their uses relating to educational purposes have, however, been poorly documented.

Wewould like to propose an innovative use of disposable gloves in hand anatomy teaching. Hand anatomy can beparticularly intricate and can often prove to be challenging for young medical students, junior doctors and surgical trainees.

A powder-free latex glove of suitable size is chosen by a tutor to ensure a comfortable fit for the trainee's hand. Basic outlines of bones, muscle and tendon attachments, blood vessels and nerves can then be subsequently drawn on with a pen, thereby providing the trainee with a useful visual aid [Figures 1-3]. This model is particularly good for demonstrating incisions for surgical exposures for acute and elective procedures. Local flaps can be drawn and raised using double gloves of two different colours. Furthermore, this model can also be used to facilitate the understanding of hand injuries and their treatment to patients as well as hand therapists.

This educational tool is extremely versatile, and the inclusion of intricate anatomical details can be tailored to the trainee's current level of training or above. It is a cheap learning resource, can be used in numerous settings and includes materials readily available in all clinical environments around the hospital. Moreover, this technique ensures dynamic learning of anatomy as movements of muscles and tendons are displayed after the glove is fitted and trainees are more likely to understand tendon attachments and muscle actions.

We find this method quick, easy, cheap and efficient in teaching trainees about hand anatomy while appreciating the dynamic advantage of this technique and simply using basic material already at the clinician's disposal.

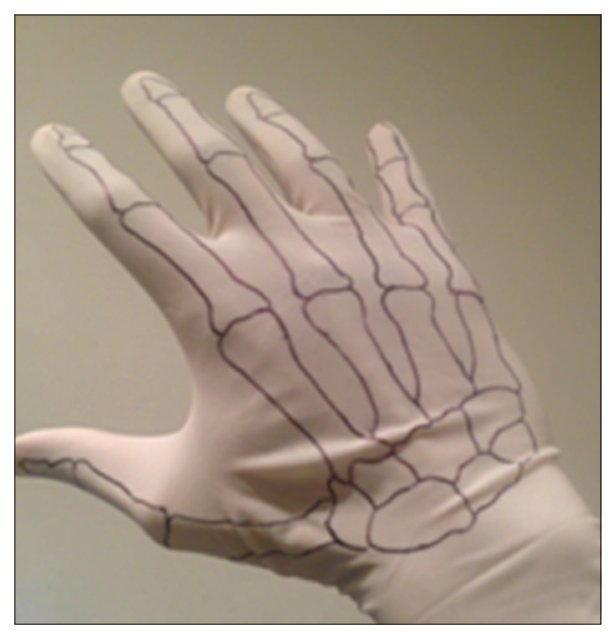

Figure 1: Surgical glove model -Dorsal bony outline

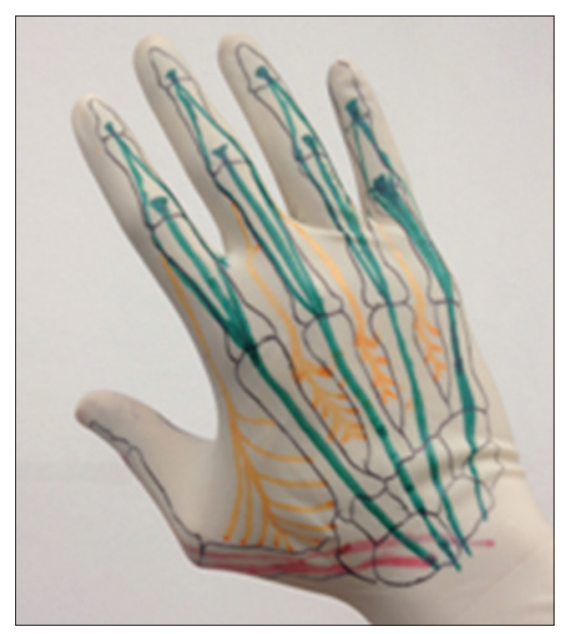

Figure 2: Dorsal bony and soft tissue outline

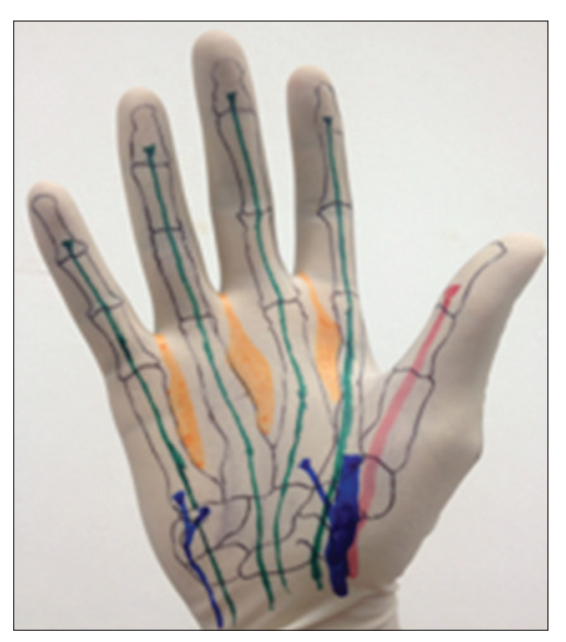

Figure 3: Volar bony and soft tissue outline

\section{Financial support and sponsorship} Nil. 


\title{
Conflicts of interest
}

There are no conflicts of interest.

\author{
Amitabh Thacoor, Diaa Othman, \\ Sharmila Jivan \\ Department of Plastic Surgery, Pinderfields Hospital, \\ Wakefield, England, UK \\ Address for correspondence: \\ Mr. Amitabh Thacoor, Department of Trauma and \\ Orthopaedics Surgery, St. Thomas' Hospital, \\ London, SE1 7EH, UK. \\ E-mail: amitabh.thacoor@doctors.org.uk
}

\section{REFERENCES}

1. Tang SW, Bebbington A. Fingerless gloves for hand trauma cases. Ann R Coll Surg Engl 2011;93:175.

2. Guirguis EM, Bell MS. The wrist tourniquet: An alternative technique in hand surgery. J Hand Surg Am 1990;15:516-9.

3. Hou SM, Urbaniak JR. Use of the surgical glove in microsurgery. J Reconstr Microsurg 1987;4:45-8.

This is an open access article distributed under the terms of the Creative Commons Attribution-NonCommercial-ShareAlike 3.0 License, which allows others to remix, tweak, and build upon the work non-commercially, as long as the author is credited and the new creations are licensed under the identical terms.

\begin{tabular}{|l|l|}
\hline \multicolumn{2}{|c|}{ Access this article online } \\
\hline Quick Response Code: & Website: \\
\hline & www.ijps.org \\
\cline { 2 - 2 } & Dol: \\
\hline
\end{tabular}

How to cite this article: Thacoor A, Othman D, Jivan S. Disposable gloves as an educational tool in teaching hand anatomy. Indian J Plast Surg 2016;49:287-8. 